University of Wollongong

Research Online

Faculty of Engineering and Information

Faculty of Engineering and Information

Sciences - Papers: Part A

Sciences

$1-1-2014$

\title{
The formation of complex microstructures after different deformation modes in advanced high-strength steels
}

Ilana Timokhina

Deakin University, Ilana.Timokhina@eng.monash.edu.au

Elena V. Pereloma

University of Wollongong, elenap@uow.edu.au

Peter Hodgson

Deakin University

Follow this and additional works at: https://ro.uow.edu.au/eispapers

Part of the Engineering Commons, and the Science and Technology Studies Commons

Research Online is the open access institutional repository for the University of Wollongong. For further information contact the UOW Library: research-pubs@uow.edu.au 


\title{
The formation of complex microstructures after different deformation modes in advanced high-strength steels
}

\author{
Abstract \\ The microstructure of transformation induced plasticity (TRIP) and dual phase (DP) multiphase steels \\ after stamping of an industrial component at different strain levels was investigated using transmission \\ electron microscopy. The TRIP steel microstructure showed a more complex dislocation substructure of \\ ferrite at different strain levels than DP steel. The deformation microstructure of the stamped parts was \\ compared to the deformation microstructure in these complex steels for different "equivalent" tensile \\ strains. It was found that the microstructures are similar only at high levels of strain (>10 pct) for both \\ steels.

\section{Keywords} \\ microstructures, after, different, deformation, complex, modes, formation, advanced, high, strength, steels

\section{Disciplines} \\ Engineering | Science and Technology Studies

\section{Publication Details} \\ Timokhina, I. B., Pereloma, E. \& Hodgson, P. (2014). The formation of complex microstructures after \\ different deformation modes in advanced high-strength steels. Metallurgical and Materials Transactions \\ A: Physical Metallurgy and Materials Science, 45 (10), 4247-4256.
}




\title{
The Formation of Complex Microstructures After Different Deformation Modes in Advanced High-Strength Steels
}

\author{
ILANA TIMOKHINA, ELENA PERELOMA, and PETER HODGSON \\ The microstructure of transformation induced plasticity (TRIP) and dual phase (DP) multi- \\ phase steels after stamping of an industrial component at different strain levels was investigated \\ using transmission electron microscopy. The TRIP steel microstructure showed a more complex \\ dislocation substructure of ferrite at different strain levels than DP steel. The deformation \\ microstructure of the stamped parts was compared to the deformation microstructure in these \\ complex steels for different "equivalent" tensile strains. It was found that the microstructures \\ are similar only at high levels of strain $(>10 \mathrm{pct})$ for both steels.
}

DOI: $10.1007 / \mathrm{s} 11661-014-2376-0$

(C) The Minerals, Metals \& Materials Society and ASM International 2014

\section{INTRODUCTION}

THE development of advanced high strength steels (AHSS) for the automotive industry has been a major theme over the past decade or so. This has led to the introduction of steels with complex microstructures that provide a better balance of strength and ductility. The two main steel types that have been developed to the stage of commercial production are dual phase (DP) and transformation induced plasticity (TRIP) steels. ${ }^{[1,2]}$ The DP steels consist of a microstructure of ferrite and martensite, whereas the TRIP steels contain ferrite, bainite, retained austenite, and martensite.

Both the microstructures offer enhanced ductility over their precipitation-hardened ferrite equivalent strength grades. In the case of DP steels, this is due to the reduction in yield strength through the introduction of dislocations into the ferrite as a result of the volume change associated with the formation of martensite. ${ }^{[3]}$ The martensite then provides strengthening at larger strains, essentially through a composite effect. Hence, the combination of low yield strength and high tensile strength provides high levels of work hardening and reduced localized deformation in sheet forming. ${ }^{[4]}$

For the TRIP steels, the situation is more complex. A large component of the increased ductility comes from the TRIP effect associated with deformation-induced transformation of the retained austenite to martensite. ${ }^{[5,6]}$ The bainite and the newly formed martensite then produce a composite hardening at higher strains. Depending on the steel composition and manufacturing routes, there may also be some martensite present in the initial microstructure leading to a combined DP/TRIP effect.

ILANA TIMOKHINA, Senior Research Academic, and PETER HODGSON, ARC Laureate Fellow, Alfred Deakin Professor, Director, are with the Institute for Frontier Materials, Deakin University, Geelong, VIC, Australia. Contact e-mail: ilana.timokhina@ deakin.edu.au ELENA PERELOMA, Director, is with UOW Electron Microscopy Center, Engineering Materials Institute, University of Wollongong, Wollongong, NSW, Australia.

Manuscript submitted October 2, 2013.

Article published online June 14, 2014
There have been some works to characterize the formability, fatigue, and crash behavior of these steels in the as-received condition; i.e., after processing but before any forming operations. ${ }^{\left[i^{-}-9\right]}$ However, these steels are cold formed by stamping, or hydroforming, or other processes prior to their incorporation into the final component. Then, this cold working is known to affect also the performance of the steel. For example, in a TRIP steel, testing of the as-received material will involve the effect of the retained austenite, whereas in the formed part, the volume fraction of retained austenite in the same steel will approach zero and be replaced by martensite.

In the current work, two key aspects are considered. The first is to understand how the room-temperature stamping of an industrial component affects the dislocation structures at various strain levels. This involved the stamping of a large cross member with samples taken from various locations where the strain was either known experimentally or predicted using a validated finite element model. ${ }^{[10]}$ These formed components have complex shapes, and hence, it is not generally possible to determine other properties such as fatigue or crash behavior by taking the samples out of the formed component. Rather, the general approach is to apply an equivalent strain through another method, such as using a larger tensile sample and then after a prescribed deformation, cutting out smaller samples for testing, or using other deformation modes such as rolling. There has been little work to consider whether these processes do, in fact, develop equivalent structures. Some early work on bake hardening steels used rolling, but these steels have a very simple microstructure. Therefore, the second aspect of this work is to compare the deformation structures in these complex steels for different "equivalent" tensile strains with those from the actual formed component.

\section{EXPERIMENTAL}

Commercial DP and TRIP sheet steels of 2-mm thickness were produced by standard cold rolling and 
intercritical route at $1053 \mathrm{~K}\left(780^{\circ} \mathrm{C}\right)$ for 180 seconds after that the DP was quenched, whereas the TRIP steel was cooled to $673 \mathrm{~K}\left(400{ }^{\circ} \mathrm{C}\right)$ and held for 300 seconds before quenching. The compositions of the steels are shown in Table I. The pre-strain conditions of 5, 10, and 20 pct were obtained by cold rolling (i.e., plane strain) with good lubricant to minimize through thickness structure differences. Full scale stampings of an automotive front cross member, with a relativity complex channel type structure containing different draw depths along the length, were performed at the Ford Stamping Plant as outlined in Reference 10 . One cross section of the part after stretch forming was selected for strain measurements (Figure 1).

The tensile properties of the as-processed steels were measured using an Instron 4500 servohydraulic tester with a $100 \mathrm{kN}$ load cell. The equivalent strain after stamping was calculated as the largest maximum principal strain $\varepsilon_{1}$. Deformation was considered to be equivalent if the tensile strain in tensile test was equivalent to $\varepsilon_{1}$ in the local area of the sheet.

The samples for transmission electron microscopy (TEM) analysis were taken from a section that was close to plane strain deformation and with major strains (effectively equivalent tensile strains as plane strain) of approximately of 5, 10, and 20 pct for the three locations (Figure 1). TEM was carried out using a Philips CM20 TEM operating at $200 \mathrm{kV}$. Thin foils for TEM were prepared by twin jet electropolishing using a solution of 5 pet perchloric acid in methanol at $253 \mathrm{~K}$ $\left(-20^{\circ} \mathrm{C}\right)$ and an operating voltage of $50 \mathrm{~V}$. The conventional electron microscopy was conducted with a condenser aperture of $100 \mu \mathrm{m}$ nominal diameter and a nominal beam diameter of $55 \mathrm{~nm}$. The observations were made in the bright and dark imaging modes, while selected area electron diffraction (SAED) patterns were recorded from areas of interest. The microband thickness was determined using the linear intercept method on the TEM images with at least 20 intercepts at 27,500 times magnification. The dislocation density of ferrite was calculated by Reference 11:

$$
\Lambda=2 N_{\mathrm{L}} / L t
$$

Table I. Chemical Compositions of Steels, (Wt Pet)

\begin{tabular}{llcccccc}
\hline Steel & $\mathrm{C}$ & $\mathrm{Mn}$ & $\mathrm{Si}$ & $\mathrm{Al}$ & $\mathrm{Cu}$ & $\mathrm{Cr}$ & $\mathrm{P}$ \\
\hline DP590 & 0.036 & 1.08 & 1.065 & 0.018 & 0.04 & 0.083 & 0.006 \\
TRIP780 & 0.12 & 1.39 & 1.77 & 0.031 & 0.005 & 0.02 & 0.004 \\
\hline
\end{tabular}

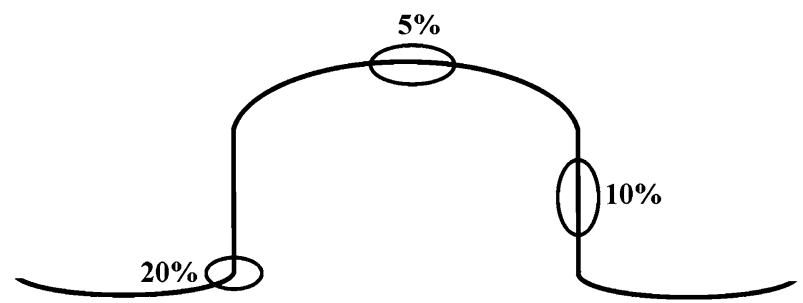

Fig. 1-Schematic representation of cross section of stamping sections with equivalent tensile strains. where $\Lambda$ is the dislocation density, $N_{\mathrm{L}}$ is the number of intersections with dislocations made by random lines of length $L$, and $t$ is the foil thickness. The foil thickness was determined from intensity oscillations in the twobeam convergent beam electron diffraction (CBED) patterns. ${ }^{[12]}$ Five bright and dark field TEM micrographs at magnification of 100,000 times with two tilting were used to calculate the average dislocation density.

The amount of the retained austenite in the TRIP steel was determined from X-ray diffraction data using the direct comparison method. ${ }^{[13]}$

\section{RESULTS AND DISCUSSION}

As mentioned above, in the current research, we addressed the observed similarities and differences in the microstructures after two different strain paths, i.e., the microstructures after pre-straining using tensile testing will be compared to those obtained by stamping with similar equivalent tensile strains.

\section{A. Microstructure and Mechanical Properties of DP and TRIP Steels After Processing}

The microstructure of the DP steel after processing consisted of $\sim 75 \pm 5$ pct polygonal ferrite with the grain size of $9 \pm 1.9 \mu \mathrm{m}$ and $\sim 15 \pm 4$ pct of martensite (Figure 2(a)). Some other minor phases such as bainite and retained austenite were present in the microstructure. The polygonal ferrite areas present in the vicinity of martensite islands displayed a local increase in the dislocation density from $0.96 \pm 0.04 \times 10^{14} \mathrm{~m}^{-2}$ for the average dislocation density to $5 \pm 0.8 \times 10^{14} \mathrm{~m}^{-2}$ near the ferrite martensite interface (Figure 2(a)). The additional dislocations in ferrite around martensite were formed during the transformation of the retained austenite to martensite in response to quenching. The strain can arise from the transformation shape change and plastic accommodation process, which occurs around martensite as they form. Hence, the behavior of the DP microstructure during pre-straining/stamping will be defined by the interaction between the newly formed mobile dislocations in ferrite as a result of deformation and those dislocations around the martensite present after quenching.

The microstructure of the TRIP steel after processing is more complex consisting of $\sim 70 \pm 3$ pct polygonal ferrite with the grain size of $4 \pm 1.5 \mu \mathrm{m}$, which is half that of the DP steel, $\sim 20 \pm 3$ pct retained austenite with average carbon content of $1.2 \pm 0.05 \mathrm{wt}$ pct, and the remaining bainite and martensite (Figure 2(b)). The retained austenite appeared to be in the form of a martensite/retained austenite constituent between the bainitic ferrite, or as islands between the polygonal ferrite grains. More detailed explanation on the microstructures of the steels is given elsewhere. ${ }^{[9]}$ Hence, the microstructural behavior of the TRIP steel during subsequent pre-straining/stamping is suggested to be determined by the interaction between the newly formed mobile dislocations in ferrite as a result of the 
transformation of retained austenite to martensite in response to the applied load (TRIP effect) and the dislocations formed as a result of deformation.

Both steels exhibited a good combination of strength and ductility, continuous yielding, low yield stress, and high work hardening rate (Figure 3 ). The logarithm of the strain-hardening rate as a function of the logarithm of the true plastic strain is shown in Figure 3(b). The stages of strain-hardening rate behavior for both steels were identified according to the changes in the slope of the curve, i.e., by the rate at which the strain hardening decreases with increasing strain. ${ }^{[14]}$ The character and number of regions or stages on the curves depend on the microstructural parameters such as grain size, volume fraction of the retained austenite or martensite. The strain-hardening rate of the DP steel is higher at low strains (stage I) than in the TRIP steel, which is believed to be associated with the interactions of the quenched-in dislocations and residual stresses with the applied stress. ${ }^{[14]}$ In stages I and III for the DP steel, the strainhardening rate decreases more rapidly for strains of $<0.003$ and $>0.02$ than in stage II for strains between 0.003 and 0.02 (Figure 3(b)). The strain-hardening rate curve of the TRIP steel showed only two stages, and the transition from stage I to stage II happened at a higher strain of 0.005 (Figure 3(b)). The differences in strainhardening behavior of the TRIP and DP steels appeared to be due to the different dislocation substructures formed in ferrite during deformation and the TRIP effect occurred in the TRIP steel as a result of applied stress. ${ }^{[14]}$

\section{B. Comparison of the Microstructures of the DP Steel After Tensile Deformation and Stamping}

The microstructural changes in the stamped sections with the strains closely equivalent to tensile strains of 5 ,

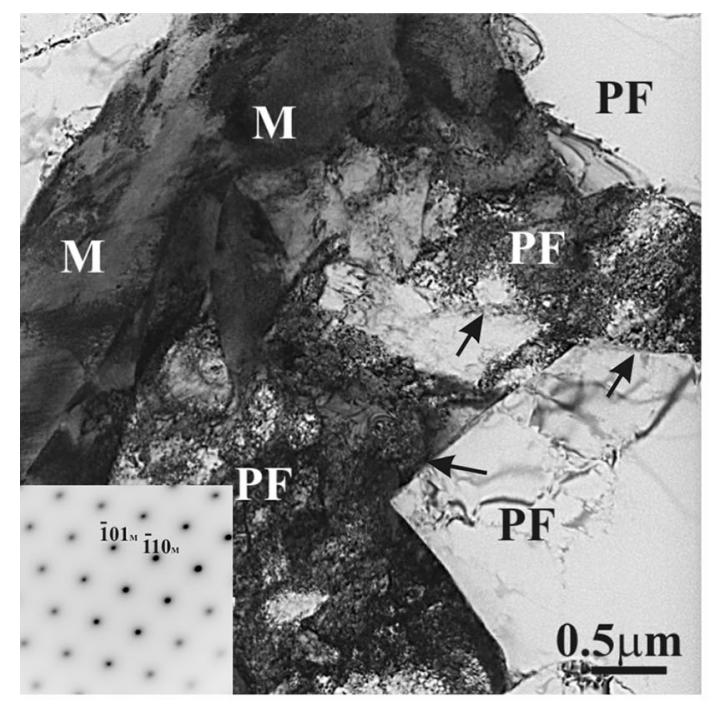

(a)

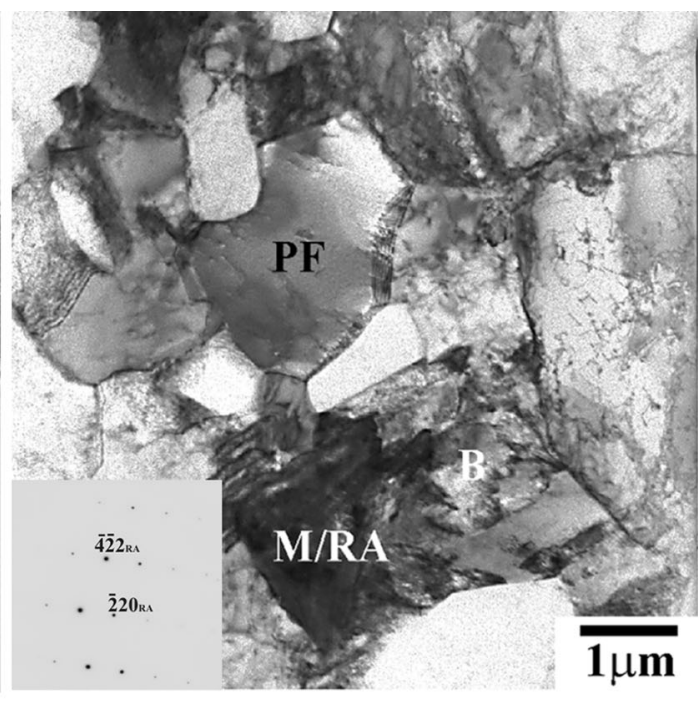

(b)

Fig. 2-Representative TEM images of the microstructure of the DP, diffraction pattern (inset) is from martensite, zone axis is [111] $\alpha(a)$, and TRIP, diffraction pattern (inset) is from retained austenite, zone axis is [113] $\gamma(b)$ steels. Arrows represent the areas with high dislocation density. $\mathrm{RA}$ is retained austenite, $\mathrm{M}$ is martensite, $\mathrm{B}$ is bainite, and $\mathrm{PF}$ is polygonal ferrite.

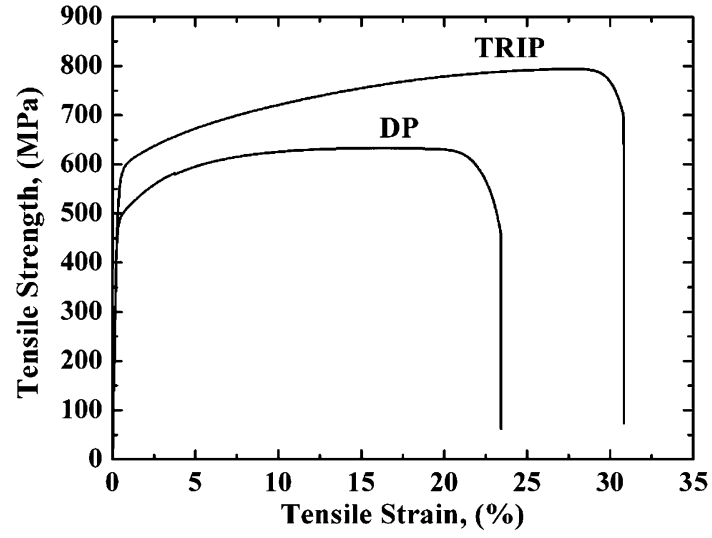

(a)

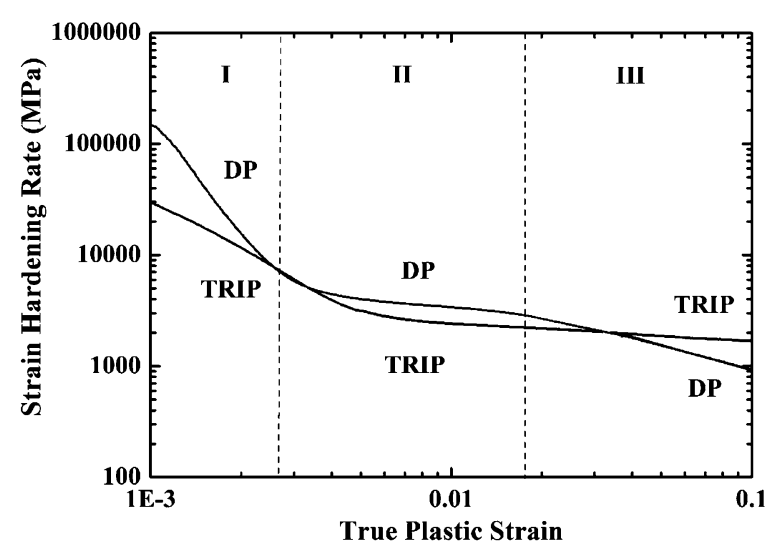

(b)

Fig. 3-Engineering stress-strain $(a)$ and strain-hardening rate from true stress-strain $(b)$ curves of the DP and TRIP steels. 
10, and 20 pct (Figure 1) and in the sections with similar pre-strain levels after tensile deformation were analyzed using TEM. The stamped regions with 5 and 10 pct of deformation experienced only deformation in tension, while the 20 pct region was formed under tension and compression deformation modes as predicted from the finite element model.

The DP steel samples from the cross section of the stamped part with an equivalent 5 pct tensile strain (Figure 1) only showed an increase in the dislocation density of the polygonal ferrite, particularly in the regions adjacent to hard martensite islands (Figures 4(a), (b) and Table II). In comparison, straining to 5 pct in tension led to the formation of a more complex dislocation substructure with the formation of incipient dislocation walls as the dominant dislocation substructure of the ferrite (Table II and Figure 4(c)).

The prevailing dislocation substructure of the ferrite after 10 pct deformation in tension was cell formation (Figure 5(a)), while the microstructure of similar stamping part showed a more complex dislocation substructure of ferrite: (i) cells and (ii) parallel dislocation walls (Table II). It was obvious that the ferrite grains near the martensite islands were more plastically deformed than the other grains (Figure 5(b)). The dislocation cells possessed low angles of boundary misorientation (2 to 3 deg) and an equiaxed shape with an average size of $0.08 \pm 0.007 \mu \mathrm{m}$ (Figure 5(c)). They had thick or diffused cell walls and an increased dislocation density in the cell interiors (Figure 5(d)). Although some ferrite grains showed the dislocation cell formation, the dominant dislocation substructure appeared to be the parallel dislocation walls or microbands (Figure 5(e)) in this cross section. The bands had parallel thick dislocation walls with a low dislocation density in the band interior. The average thickness of microbands was $0.3 \pm 0.08 \mu \mathrm{m}$, and the angle of grain boundary misorientation was 2 to $6 \mathrm{deg}$ (Figure 5(d)). Moreover, the formation of two parallel sets of microbands with an average thickness of 0.1 and $0.5 \mu \mathrm{m}$ (Figure 5(f)) was observed. It should be noted that the formation of a similar dislocation substructure has been reported ${ }^{[14]}$ for the DP steel for the true plastic strain of $>14$ pct. It appeared that the dislocation substructure of ferrite in the DP steel after stamping is more complex than after deformation in tension at the strain levels of 5 and 10 pct.

The microstructural changes in ferrite of the DP steel after stamping with an equivalent strain level of 20 pct led to the formation of: (i) cells, (ii) parallel microbands

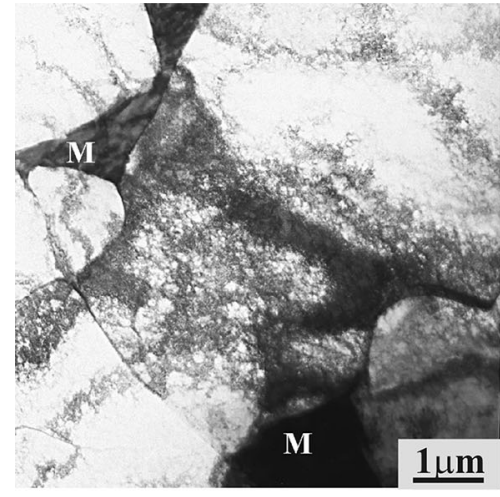

(a)

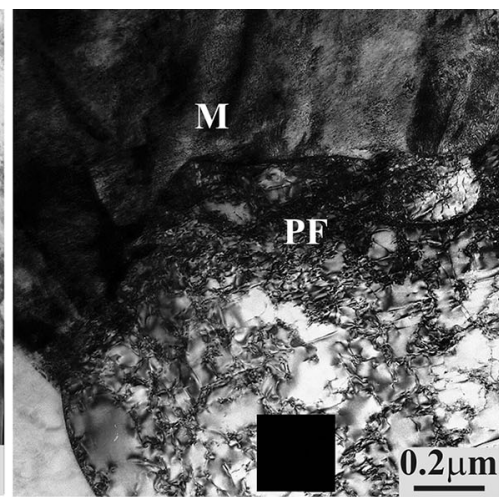

(b)

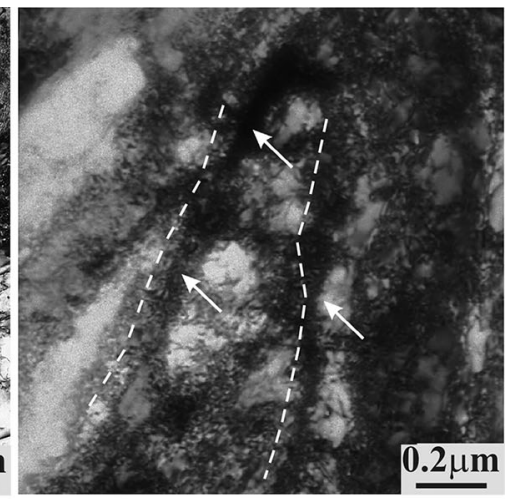

(c)

Fig. 4-TEM images of the DP steel from stamping cross section with equivalent tensile strain of 5 pct $(a, b)$ and after tensile test with prestraining of 5 pct $(c)$. Arrows indicate the microbands walls. $\mathrm{M}$ is martensite and $\mathrm{PF}$ is polygonal ferrite.

Table II. Summary of Dislocation Substructure Development in the Samples Strained in Tension and After Stamping with Equivalent Strain Levels

\begin{tabular}{|c|c|c|c|c|}
\hline \multirow{2}{*}{$\begin{array}{l}\text { True Plastic } \\
\text { Strain, (Pct) }\end{array}$} & \multicolumn{2}{|c|}{$\mathrm{DP}$} & \multicolumn{2}{|c|}{ TRIP } \\
\hline & Tensile & Stamping & Tensile & Stamping \\
\hline 5 & $\begin{array}{l}\text { occasional formation of } \\
\text { the incipient dislocation } \\
\text { walls }\end{array}$ & $\begin{array}{l}\text { increase in the dislocation } \\
\text { density of ferrite predom- } \\
\text { inantly in the adjacent to } \\
\text { martensite areas }\end{array}$ & $\begin{array}{l}\text { cells, martensite } \\
\text { (TRIP effect) }\end{array}$ & $\begin{array}{l}\text { cells, microbands, twinning } \\
\text { of retained austenite }\end{array}$ \\
\hline 10 & $\begin{array}{l}\text { fully developed cell } \\
\text { dislocation substructure }\end{array}$ & $\begin{array}{l}\text { microbands as a predomi- } \\
\text { nant dislocation substruc- } \\
\text { ture and cells formation }\end{array}$ & $\begin{array}{l}\text { cells, martensite } \\
\text { (TRIP effect) }\end{array}$ & $\begin{array}{l}\text { cells, deformation bands } \\
\text { with different orientations, } \\
\text { retained austenite twinning }\end{array}$ \\
\hline 20 & $\begin{array}{l}\text { well-developed cell dislocat } \\
\text { tion walls, martensite twi }\end{array}$ & $\begin{array}{l}\text { n substructure and deforma- } \\
\text { ning }\end{array}$ & $\begin{array}{l}\text { cells, microbands, } \\
\text { and shear bands }\end{array}$ & and TRIP effect \\
\hline
\end{tabular}




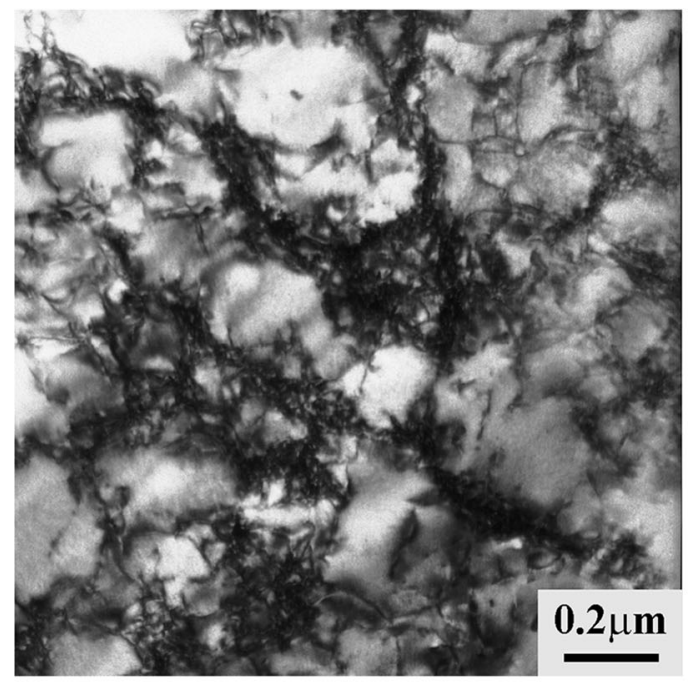

(a)

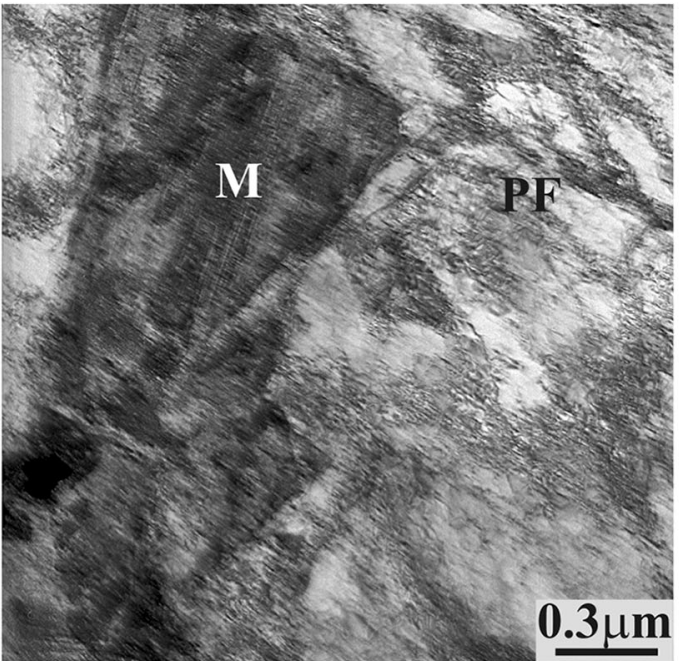

(c)

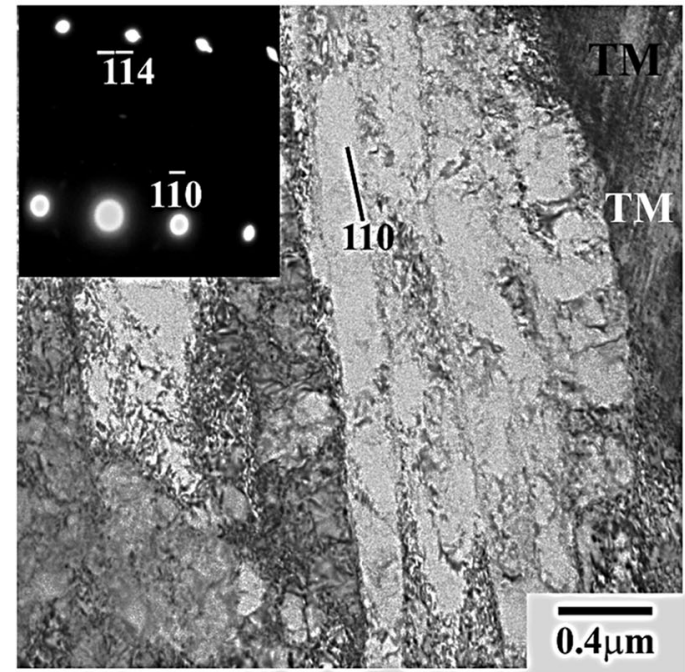

(e)

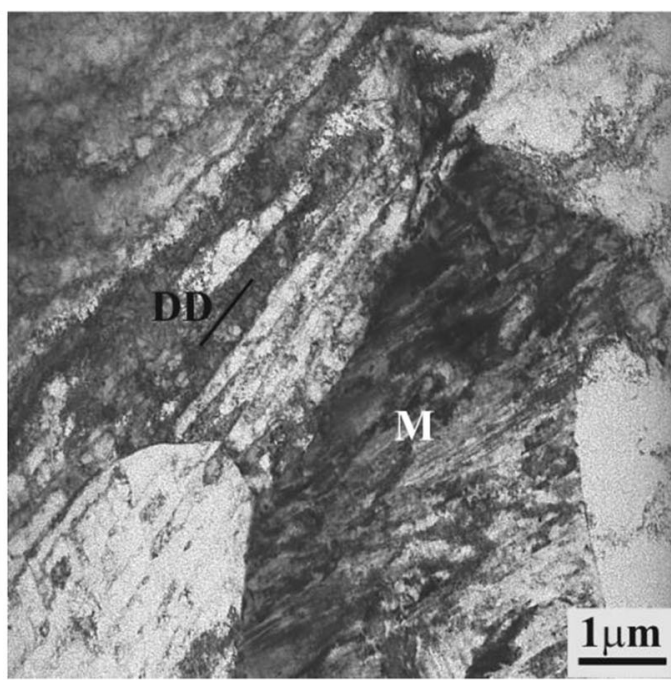

(b)

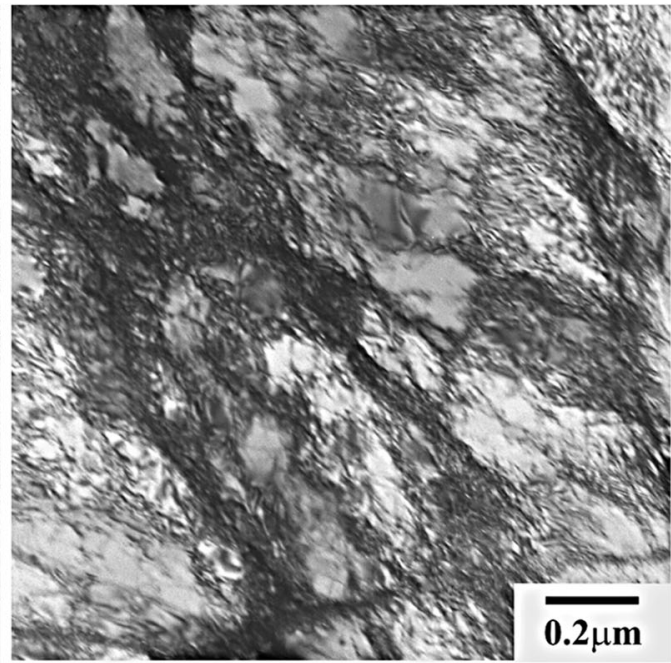

(d)

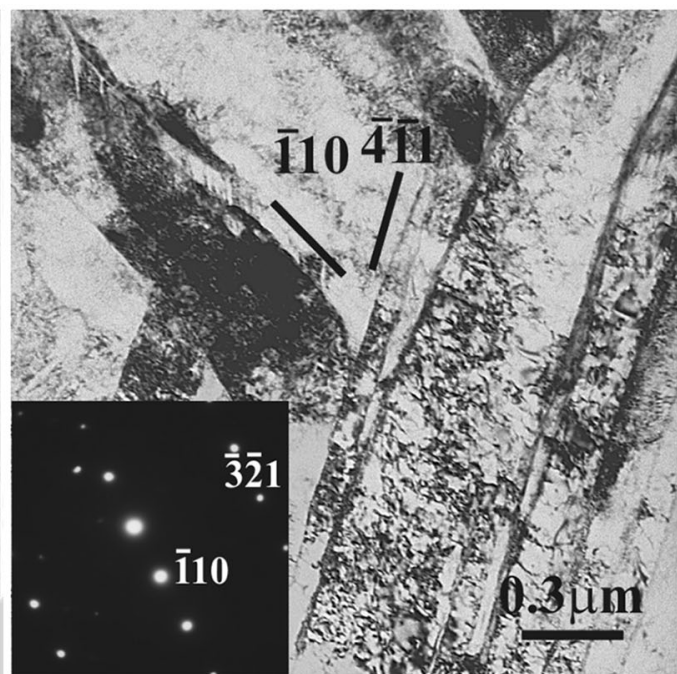

(f)

Fig. 5-TEM images of dislocation substructure formed in ferrite of the DP steel after pre-straining to 10 pct $(a)$ and stamping with equivalent strain of 10 pct: $(b, c)$ deformation bands and cells formation nearby martensite, $(d)$ cells, $(e)$ formation of microbands parallel to (110) $\alpha$ plane (zone axis is $[221] \alpha)$, and $(f)$ two sets of microbands (zone axis is [115] $\alpha$ ). M is martensite, TM is twinned martensite, and DD is deformation direction. 


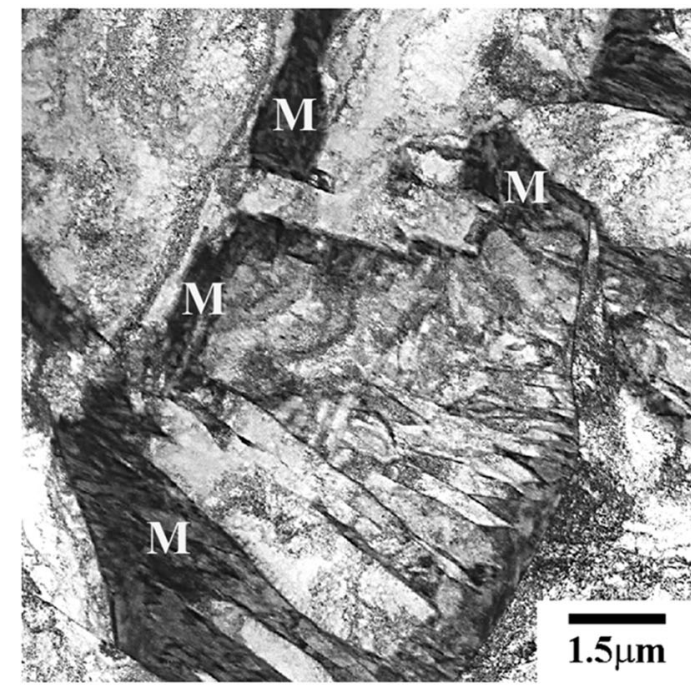

(a)

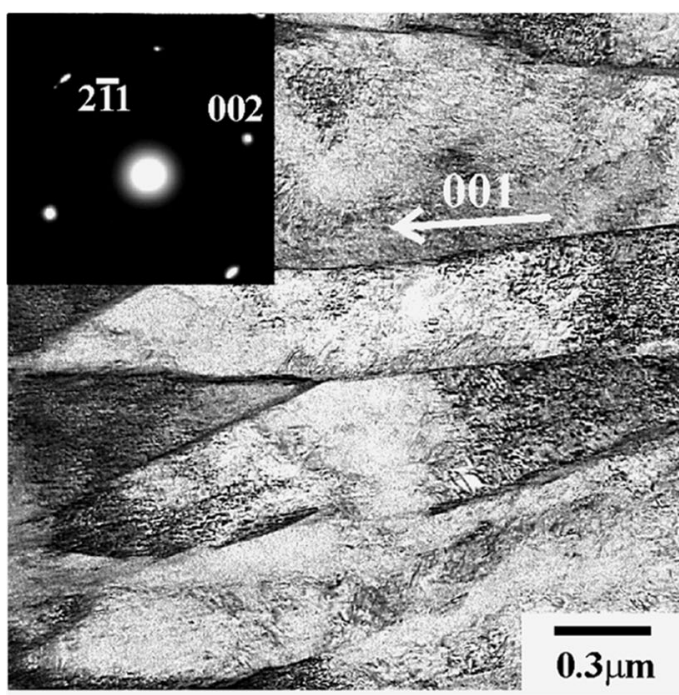

(c)

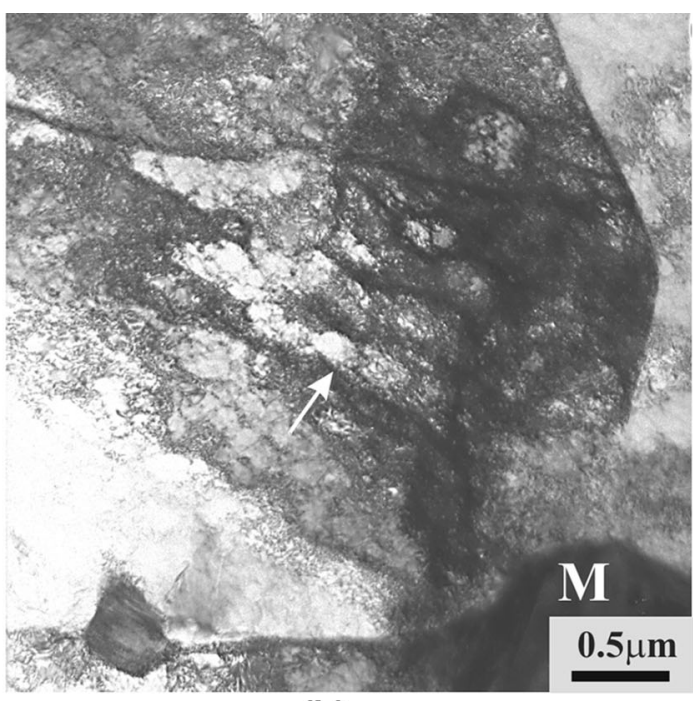

(b)

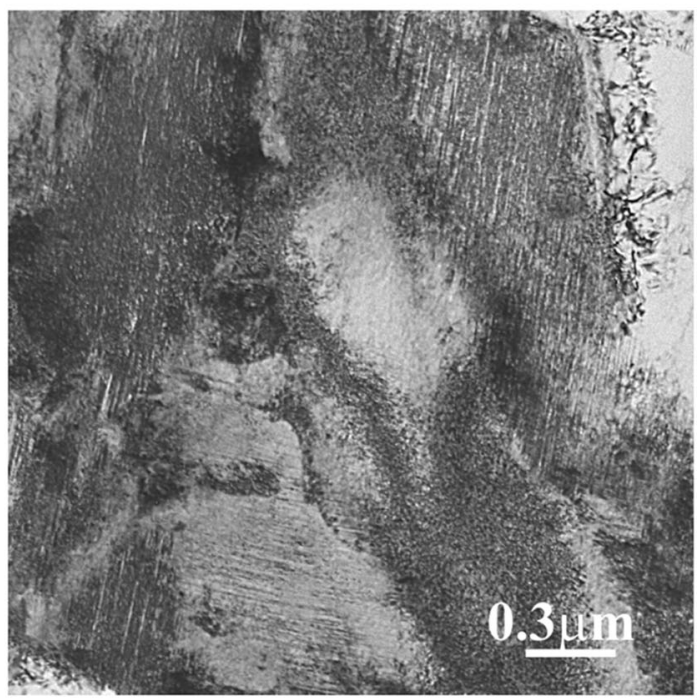

(d)

Fig. 6-Dislocation substructure of ferrite in the DP steel after stamping with equivalent strain of 20 pct: $(a)$ affected ferrite gains near martensite, $(b)$ dislocation cell substructure $(c)$ deformation bands in ferrite near martensite (zone axis is [120] $\alpha$ ), and (d) twinned martensite. M is martensite.

with sharp and thick dislocation walls, (iii) bands with different orientations within one ferrite grain (Table II). As in the previous cases, the most affected grains were ferrite grains near martensite (Figure 6(a)). The cell substructure was well developed with the average cell size of $0.08 \pm 0.007 \mu \mathrm{m}$ (Figure 6(b)). The average thickness of deformation bands was $0.3 \pm 0.07 \mu \mathrm{m}$. Moreover, some individual ferrite grains showed the propagation of sharp deformation bands from hard martensite islands (Figure 6(c)). Another important aspect that should be considered at this level of strain is martensite twinning, which could be evidence that the strain was concentrated not only in soft ferrite matrix but also had propagated into the hard martensite (Figure 6(d)). It is important to highlight that a similar microstructure was observed in the samples after prestraining in tension to 20 pct.
In summary, the microstructure of the stamped samples of the DP steel is similar to that after prestraining only at high strain level of 20 pct.

\section{Comparison of the Microstructures of the TRIP Steel After Tensile Deformation and Stamping}

The complexity of the TRIP steel behavior under applied stress lays in the presence of retained austenite in the microstructure. It has been shown that the retained austenite is less stable under tensile loading than under compressive loading, as the normal component (hydrostatic) of the applied load is positive in tension and negative in compression. ${ }^{[15]}$

The dominant dislocation substructure of ferrite in the stamped cross section, for 5 pct pre-straining, was cells, with rather sharp dislocation walls, and grain 
(a)

(c)

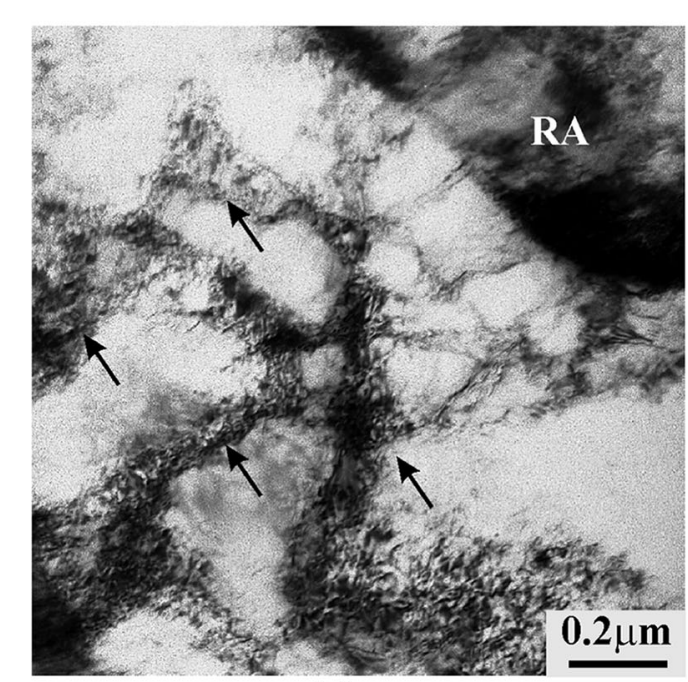

(e)
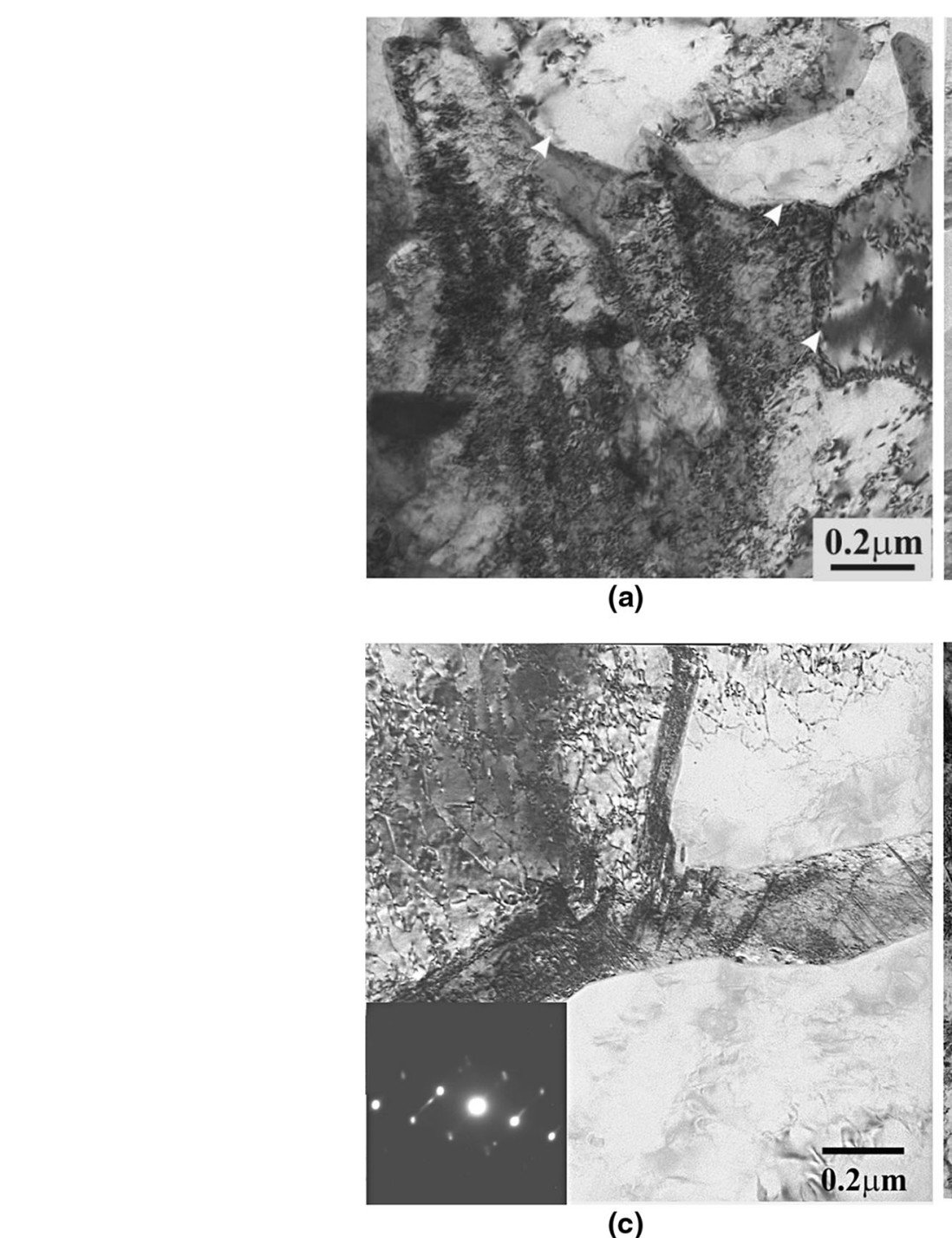

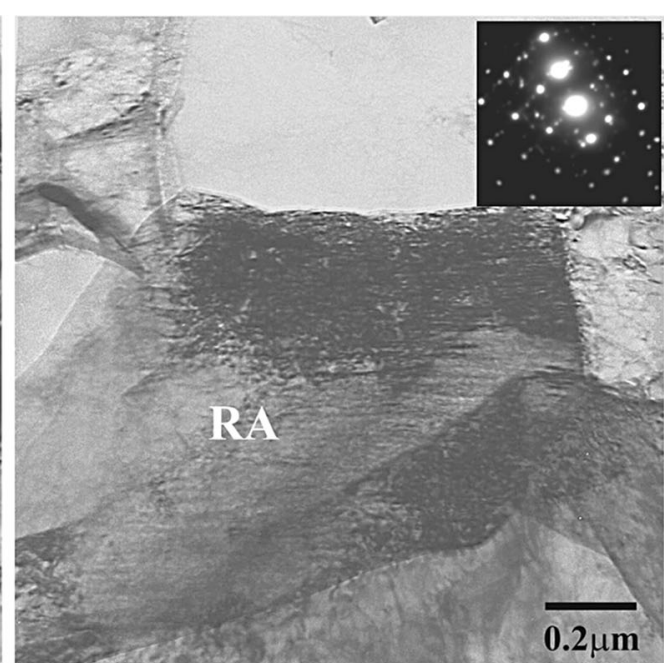

(b)

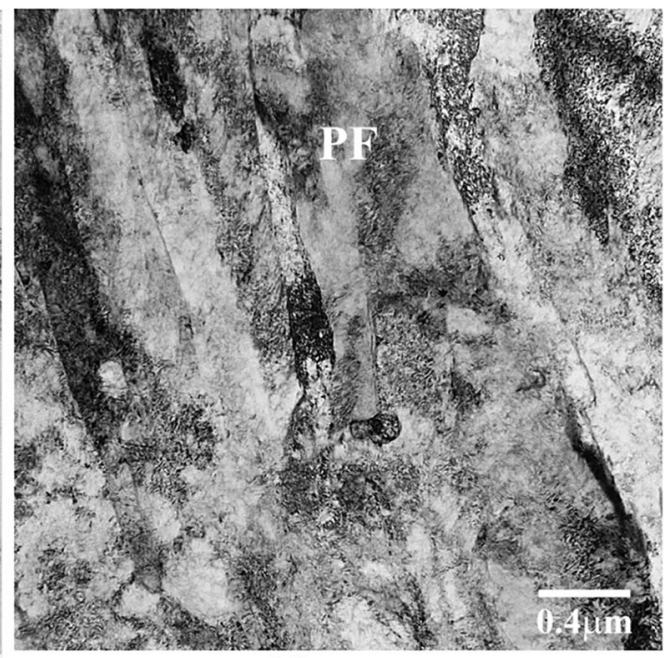

(d)

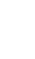




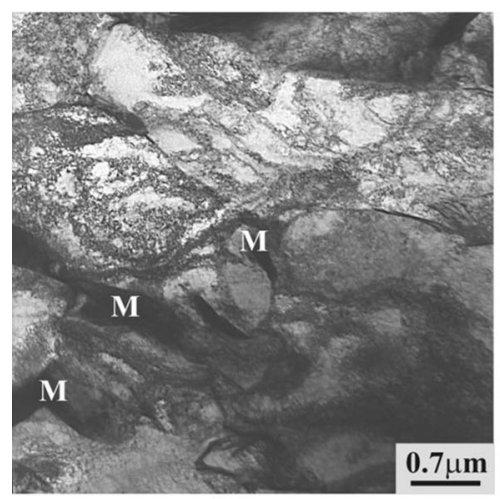

(a)

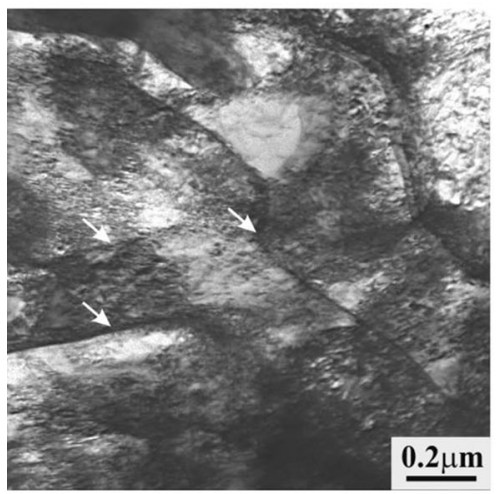

(d)

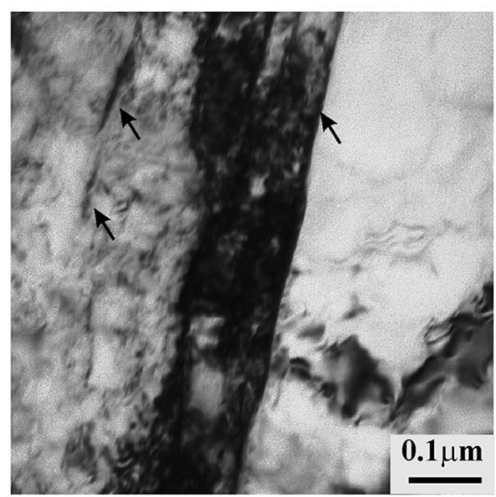

(g)

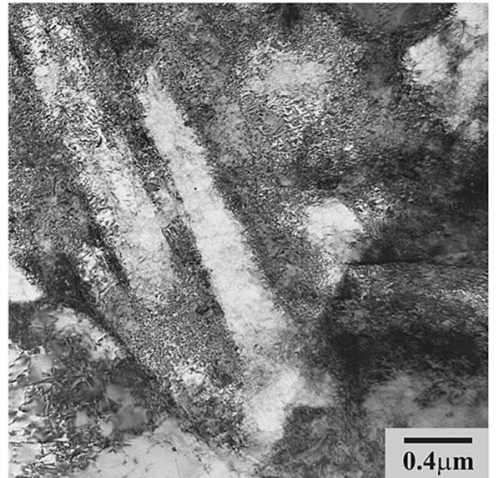

(b)

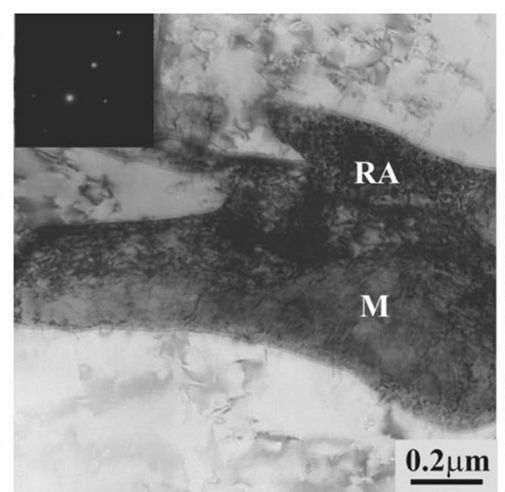

(e)

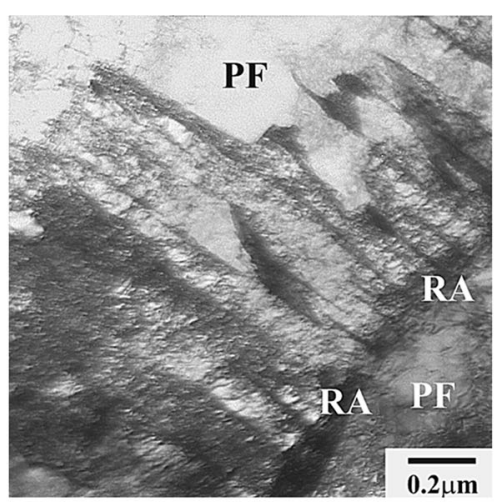

(c)

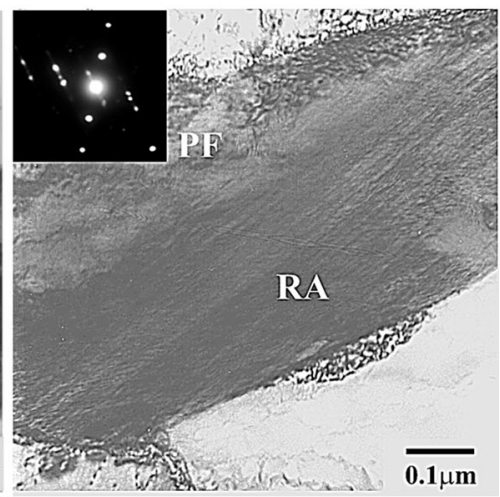

(f)

Fig. 8-TEM micrographs from the cross section of cold-stamping parts after 10 and 20 pct ( $a$ through $f$ ) of equivalent tensile deformation and from 5 pct of pre-straining $(g)$ in the TRIP steel: (a) ferrite grains in the vicinity of martensite, (b through d) deformation bands in ferrite, ar-

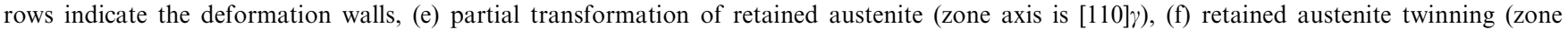

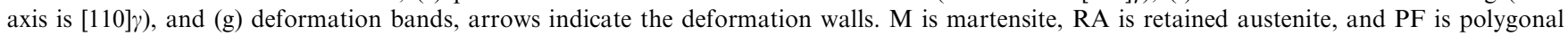
ferrite.

interior was free of dislocations (Figure 7(a)). An intriguing feature of the microstructure of this cross section was preferential retained austenite twinning rather than retained austenite to martensite transformation (TRIP effect) (Figures 7(b), (c)). Moreover, it appeared that the twinning propagates stress into the adjoining ferrite matrix causing the local dislocation density to increase (Figure 7(b)) and formation of local deformation microbands in the areas adjacent to the twinned austenite (Figure 7(d)). Some of the retained austenite crystals were partially twinned, i.e., one part of the crystal was twinned while another was undeformed (Figure 7(c)), which could be a result of non-homogeneous redistribution of carbon within the retained austenite islands. As was reported earlier, ${ }^{[16]}$ the twinning mode of austenite deformation is preferential even at a high strain level of 0.17 , if the retained austenite average carbon content is $\sim 1.8 \mathrm{wt} \mathrm{pet}^{[16]}$ and due to this, the increase in SFE and reduction in $M_{\mathrm{S}}$ made twinning the preferential behavior at these strains for this steel. 
Furthermore, after twinning, the retained austenite crystal is stabilized even further due to matrix constraints for the martensite transformation. The volume fraction of the retained austenite in the stamped cross section, for 5 pct pre-straining, slightly decreased to $17 \pm 2$ pct compared to the initial condition that indirectly confirmed preferential retained austenite twinning than TRIP effect.

The volume fraction of the retained austenite after 5 pct pre-straining in tension decreased to 12 pct, and the twinned austenite was not a representative feature of the microstructure. The dominant dislocation substructure of polygonal ferrite after 5 pct straining in tension was dislocation cells with an average size of $0.2 \mu \mathrm{m}$ (Figure 7(e) and Table II). The deformation microbands were not observed in ferrite after pre-straining. It appeared that the retained austenite is less stable for the pre-strained condition, and the TRIP effect promotes the development of cells in ferrite. As is well known, martensite transformation is associated with a volume increase, and compressive loading suppresses this and stabilizes the retained austenite. ${ }^{[1]}$ The straininduced martensite transformation is retarded under plane- strain conditions in comparison with tensile testing, ${ }^{[18]}$ whereas the biaxial stretching resulted in faster transformation of the retained austenite than in the uniaxial tension condition. ${ }^{[19]}$ Thus, the magnitudes of deviatoric and hydrostatic stress components as well as the stress triaxiality influence the rate of deformationinduced austenite transformation.

TEM on the TRIP samples from the cross sections representing 10 pct and 20 pct pre-straining also revealed that ferrite plastically deformed earlier than bainite or austenite, causing the ferrite grains to flow around bainite, retained austenite, and martensite (Figure $8(\mathrm{a}))$. The retained austenite volume fraction decreased in the stamped cross section to $15 \pm 2$ and to $5 \pm 3$ pct, representing 10 and 20 pct of pre-straining, respectively. The most strain-affected grains were those ferrite grains that were in the vicinity of retained austenite or martensite. These grains demonstrated a variety of dislocation substructures from cells to deformation bands. Moreover, the deformation bands, observed within these grains, had different orientations confirming the complexity of the strain paths during stamping (Figures 8(b) through (d)). The average thickness of the deformation bands was $0.3 \pm 0.1 \mu \mathrm{m}$ (Figures 8(b) through (d)). It appeared that for the retained austenite, both deformation mechanisms, i.e., twinning and strain-induced transformation of retained austenite, were activated during stamping in areas with equivalent strain exceeding 10 pct. The twinned and partially transformed retained austenite was observed along with martensite (Figures 8(e), (f)).

Comparison of the microstructure development after stamping and pre-straining with similar strain levels of 10 and 20 pet showed the similarities of the microstructures after 20 pct and differences up to 10 pet strain. In particular, the complex dislocation substructure including cells, microbands, shear deformation bands, and high density of dislocation tangles was observed after 20 pet straining in tension and stamping, while after
10 pet straining in tension, the dominant dislocation configuration was cells. Only a negligible amount $(\sim 3$ pct $)$ of the retained austenite remained in the microstructure after 20 pct pre-straining, while after stamping, the retained austenite tended to be twinned.

It appeared that with an increase in strain, the microstructures of both steels became less affected by the mode of deformation. It also appears that the microstructure of both the steels was more inhomogeneous after stamping with ferrite grains in the vicinity of hard martensite crystals exhibiting a more advanced stage of deformation compared to those located far away.

\section{CONCLUSIONS}

The microstructure development of two multiphase high strength steels, TRIP and DP, after pre-straining and stamping was investigated. The main conclusions are

1. the microstructures after tensile straining can represent the microstructure after stamping only at high levels of strain ( $>10$ pct) for the both steels;

2. the TRIP steel microstructure demonstrated a more complex dislocation substructure of ferrite due to the TRIP effect and retained austenite twinning;

3. the mode of deformation determined the promotion of the TRIP effect or retained austenite twinning in the TRIP steel.

\section{ACKNOWLEDGMENTS}

One of the authors (P.D.H.) acknowledges the support of the ARC Laureate Fellowship scheme.

\section{REFERENCES}

1. Y. Sakuma, O. Matsumura, and H. Takechi: Metall. Trans., 1991, vol. 22, pp. 489-98.

2. R.G. Davies: Metall. Trans., 1978, vol. 9, pp. 41-52.

3. A.H. Nakagawa and G. Tomas: Metall. Trans., 1985, vol. 16, pp. 831-40.

4. M.S. Rashid: Proc. AIME Symp., TMS-AIME, Warrendale, PA., 1994, vol. 244, pp. 1-2.

5. O. Matsumura, Y. Sakuma, and H. Takechi: Scripta Mater., 1987, vol. 21, pp. 1301-06.

6. G.R. Speich and V.A. Demarest: Metall. Trans, 1981, vol. 12, pp. 1419-28.

7. T. Hilditch, I.B. Timokhina, E.V. Pereloma, and P.D. Hodgson: Metall. Mater. Trans. A, 2009, vol. 40A, pp. 342-49.

8. B. Yan and D. Urban: "Characterization of Fatigue and Crash Performance of New Generation High Strength Steels for Automotive Applications (Phase I and Phase II)" AIST: Pittsburgh Report No: TRP 0038, 2003.

9. I.B. Timokhina, P.D. Hodgson, and E.V. Pereloma: Metall Mater. Trans., 2007, vol. 38A, pp. 2442-54.

10. S.A. Asgari, M. Pereira, B.F. Rolf, M. Dingle, and P.D. Hodgson: J. Mater. Process. Technol., 2008, vol. 203, pp. 129-36.

11. P.B. Hirsch, R.B. Nicholson, A. Howie, D.W. Pashley, and M.J. Whelan: Electron Microscopy of Thin Crystals, Butterworths, London, 1965, p. 51.

12. P.M. Kelly, A. Jostsons, R.G. Blake, and J.G. Napier: Phys. Stat Sol., 1975, vol. 31, p. 771. 
13. B.D. Cullity: Elements of X-Ray Diffraction, Addison-Wesley, New York, 1978, p. 555.

14. D.A. Korzekwa, D.K. Matlock, and G. Krauss: Metall. Trans., 1984, vol. 15, pp. 1221-28.

15. I.Y. Pyshmintsev, M. De Meyer, B.C. De Cooman, R.A. Savray, V.P. Shveykin, and M. Vermeulen: Metall. Mater. Trans. A, 2002, vol. 33 A, p. 1659.
16. I.B. Timokhina, P.D. Hodgson, H. Beladi, and E.V. Pereloma: $L a$ Metall. Ital., 2009, vol. 101 (11-12), pp. 43-48.

17. J.R. Patel and M. Cohen: Acta Metall., 1953, vol. 1, pp. 531-38.

18. D.B. Im, C.G. Lee, S.J. Kim, and I.M.J. Park: J. Korean Inst. Met. Mater., 2002, vol. 40, pp. 8-13.

19. K. Sugimoto, M. Kobayashi, A. Nagasaka, and S. Hashimoto: ISIJ Int., 1995, vol. 35, pp. 1407-14. 